Jurnal Ilmu Dakwah Volume 39 No 2 (2019) 126-146

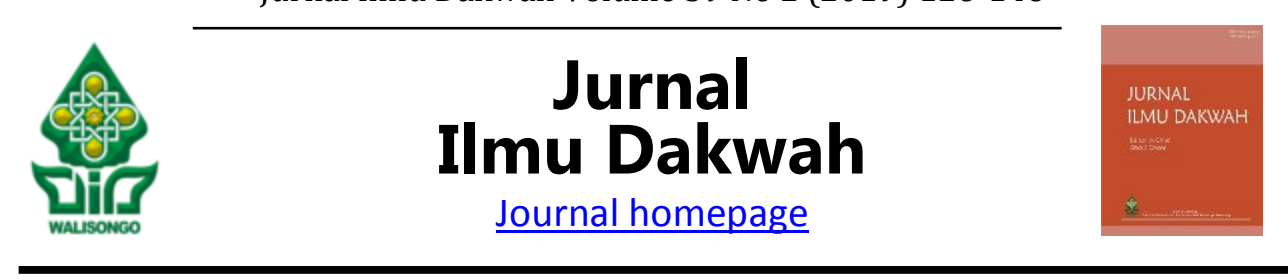

\title{
Reformulasi Metode Dakwah bi al-Lu'bah sebagai Trauma Healing pada Anak Korban Bencana Alam
}

\author{
Moh Erfan Soebahar, ${ }^{1}$ Abdul Ghoni ${ }^{2}$ \\ ${ }^{1}$ Fakultas Ilmu Tarbiyah dan Keguruan UIN Walisongo Semarang \\ ${ }^{2}$ Fakultas Dakwah dan Komunikasi UIN Walisongo \\ erfan.soebahar@walisongo.ac.id dan abdul.ghoni@walisongo.ac.id
}

\begin{abstract}
The use of the da'wah bi al lu'bah method can be implemented for children affected by natural disasters. The formulation of the da'wah method can be done by combining the da'wah method with the trauma healing technique. This research was conducted with a literary approach and supported by trauma healing activities at the 2006 earthquake site, namely Klaten District - Central Java and Sleman District - Yogyakarta. In fact researchers did not find the practice of da'wah at these two earthquake locations. The results of the study reveal the formulation of bi al lu'bah propaganda can be done in three ways, namely First, infiltration of propaganda material in the existing game. Infiltrate (infiltration) in the game commonly done by mad'u. Second, making da'wah games, can be done in various ways understood by mad'u children. Third, make poetry about propaganda material through popular songs that can be easily remembered.

\begin{abstract}
Abstrak
Penggunaan metode dakwah bi al lu'bah dapat dilaksanakan untuk anak-anak korban bencana alam. Formulasi metode dakwah ini dapat dilakukan dengan penggabungan antara metode dakwah dengan teknik trauma healing. Penelitian ini dilakukan dengan pendekatan literer dan didukung dengan kegiatan trauma healing di lokasi gempa tahun 2006, yaitu Kabupaten Klaten - Jawa Tengah dan Kabupaten Sleman Yogyakarta. Kenyataannya peneliti tidak menemukan praktik dakwah di dua lokasi gempa ini. Hasil penelitian mengungkapkan formulasi dakwah bi al- lu'bah dapat dilakukan dengan tiga cara, yaitu Pertama, penyusupan materi dakwah pada permainan yang ada. Menyusupkan (infiltrasi) pada permainan yang lazim dilakukan oleh mad'u. Kedua, membuat permainan dakwah, Membuat permainan dakwah dapat dilakukan dengan berbagai cara yang dipahami oleh mad'u anak. Ketiga, membuat syair tentang materi dakwah melalui lagu-lagu populer yang dapat mudah diingat.
\end{abstract}

Kata Kunci: Dakwah bi al lu'bah, permainan, trauma healing 


\section{Pendahuluan}

Dalam konteks interaksi sosial, dakwah mempunyai kekuatan sebagai pendorong perubahan sosial menuju tatanan masyarakat yang lebih baik. (Arifin, 1996: 39). Seorang da'i membutuhkan usaha maksimal dengan mengemas materi, metode dan unsur dakwah lainnya demi kesuksesan dakwah yang dilaksanakan. Metode dakwah, merujuk pada QS. Al Nahl, ayat 125 hanya dilakukan dengan tiga metode (al hikmah, maizah hasanah dan mujadalah). (Az Zaid, 1993: 31) Untuk mengaplikasikan tiga metode dakwah tersebut dibutuhkan kepiawaian seorang da'i. Persoalan yang seringkali muncul adalah apakah ketiga metode tersebut telah mampu mengantarkan kesempurnaan dakwah untuk menuju perubahan masyarakat yang diinginkan dan sesuai dengan segmentasi mad'u?

Asumsi sementara dapat dikatakan bahwa ketiga metode tersebut belum dapat memaksimalkan dakwah yang dilaksanakan. Dibutuhkan metode lain yang lebih sesuai dengan kondisi mad'u. Memang, untuk dapat memaksimalkan dakwah dibutuhkan kebijaksanaan (hikmah). Namun membicarakan kebijaksanaan tentunya kembali pada kondisi da'i itu sendiri. Padahal, diketahui bahwa psikologi seorang da'i terkadang beragam dan belum merambah pada sebuah kematangan psikologis. Hal ini membutuhkan kreatifitas, pemikiran, dan pengembangan dalam penggunaan metode dakwah yang sesuai dengan kondisi mad'u yang dihadapi. Kecakapan seorang da'i dalam sisi ini penting sebagai upaya pengembangan dalam melengkapi sistem, komponen dan unsur dakwah.

Anak merupakan salah satu segmentasi mad'u yang tidak dapat ditinggalkan bagi seorang da'i. Namun, kenyataannya anak seringkali dilupakan dan dianggap "bukan" bagian dari mad'u bagi pelaku dakwah. Padahal sebenarnya kegiatan dakwah bisa diawali dari seorang anak. Anak merupakan generasi bangsa yang dirinya perlu untuk diberi materi dakwah seperti orang dewasa itu sendiri. Lebih-lebih anak dalam kondisi dirinya sebagai korban bencana alam. Psikologinya pasti akan terganggu dengan adanya kejadian alam tersebut dibandingkan dengan psikologi orang dewasa. Dirinya lebih menderita, dan akan mengalami trauma psikis, bahkan fisik; apalagi bagi mereka yang kehilangan orang tuanya dalam bencana alam tersebut (Patilima, 2017: 3)

Dalam perawatan, pengawasan dan pendidikan anak, Islam telah mengajarkan untuk merawat, mengawasi dan mendidik anak. Perintah melaksanakan hal ini termaktub dalam surat al-tahrim ayat 6 (Hai orang-orang yang beriman, peliharalah dirimu dan keluargamu dari api neraka...). Perintah ini membersitkan tentang pentingnya memperlakukan anak dengan sebaik mung kin dengan kasih sayang. (Zainu, 2002: 22) lebih-lebih pada anak yang dalam kondisi dirinya sebagai korban bencana dengan berbagai "penyakit" yang disandangnya. Hal ini merupakan dasar bagi umat untuk memberikan pelayanan terbaik kepada anak-anak.

Memperlakukan anak korban bencana alam sebaik mungkin juga termaktub dalam Undang-undang Nomor 23 tahun 2002 tentang perlindungan anak, khususnya pasal 59 ("pemerintah dan lembaga negara lainnya, berkewajiban dan bertanggungjawab untuk memberikan perlindungan khusus kepada anak dalam situasi darurat"). Selain itu pasal 60 juga menyatakan bahwa ("anak dalam situasi darurat adalah anak korban bencana alam"). Kedua pasal dalam Undang-undang Nomor 23 tahun 2002 ini memberikan pengertian bahwa anak korban bencana juga menjadi fokus perhatian pemerintah.

Kembali pada persoalan dakwah, dakwah seringkali dilakukan hanya dengan metode ceramah (bi al-lisan) dengan obyek orang-orang dewasa. Padahal, merujuk pada persoalan di atas, anak juga merupakan bagian dari mad'u yang tidak dapat 
ditinggalkan. Praktek dakwah kepada anak-anak merupakan kebutuhan yang tidak dapat ditinggalkan begitu saja. Keberhasilan dakwah ditentukan oleh pemahaman seorang da'i dalam memahami mad'unya. Bukankah Nabi Muhammad telah menyampaikan dalam sebuah hadits yang diriwayatkan oleh Bukhari - Muslim ("Berbicaralah kepada (manusia) sesuai dengan kadar pikirannya") (Muriah, 2000: 34)

Mengapa dakwah tidak dapat beradaptasi dengan kondisi anak korban bencana alam?. Bukankah dalam situasi pasca bencana manusia membutuhkan spiritual baginya. Hal ini senada dengan yang disampaikan oleh Nottingham (1995: 75) "dalam kondisi ketidakberdayaan, secara psikologis agama dapat menenteramkan goncangan batin". Hal ini mengisyaratkan bahwa dakwah bagi korban bencana alam merupakan sebuah hal penting yang dinantikan oleh mereka. Mereka tidak hanya membutuhkan penanganan awal atau Psychological First Aid (PFA) dan trauma healing semata. Masyarakat membutuhkan peranan da'i dalam menetralisir beban psikologis yang disandangnya dengan materi dan nilai keagamaan. Dari sini dapat dipahami bahwa keberadaan da'i dengan metode yang sesuai dalam dakwah kepada anak-anak korban bencana alam sangat penting adanya.

Bagi anak korban bencana alam, PFA dan trauma healing memang dibutuhkan pasca bencana alam tersebut. Namun, menurut asumsi sementara peneliti, berdasarkan pada studi pendahuluan yang dilakukan pada anak-anak korban gempa di lombok tanggal 27 s.d 30 agustus 2018 dibutuhkan gabungan metode dakwah dengan PFA, trauma healing dan recreational theraphy. Penggabungan tersebut merupakan salah satu bentuk untuk menyusun metode yang sesuai dalam menangani anak korban bencana alam. Konsep Unity of sciences sebagai salah satu upaya untuk menggabungkan teori dakwah dan teori psikologis menjadi alternatif pilihan dalam mencapai kesempurnaan dakwah yang dilaksanakan.

Berdasar pada pemikiran di atas, dalam pengamatan peneliti, belum ada da'i yang secara intensif memberikan dakwah dengan metode yang dibutuhkan masyarakat, lebih-lebih dengan mengedepankan unity of sciencies di atas. Mereka hanya menggunakan metode hikmah dan mauidzah hasanah dengan memberikan materi tentang kesabaran semata, belum masuk pada penanganan psikologis korban. Hal ini yang menurut peneliti merupakan sebuah tantangan ke depan bagi da'i untuk meningkatkan kepiawaiannya dalam berdakwah kepada anak-anak korban bencana alam, khususnya dalam hal metodologi dakwah, termasuk menggunakan media yang betul-betul mampu diterapkan dalam kegiatan dakwah yang dilaksanakan tersebut.

Penelitian tentang dakwah terhadap korban bencana alam telah dilakukan oleh Wening Wihartati (2014), Dakwah pada Korban Bencana Alam dan Bencana Sosial, Kajian ini dilaksanakan dengan pendekatan kualitatif- deskriptif. Hasil penelitian menyatakan bahwa bentuk dakwah dalam menangani korban bencana alam adalah bentuk dakwah irsyad dan tathwir, dengan metode mauizah hasanah, bil mal, bil hal dan aksi kelompok. Sementara itu penelitian Dudi Imanudin E, (2010), Konseling Pasca Bencana: Telaah atas Konsep Terapi Post Traumatic Stress Disorder (PTSD) mengulas tentang kritik kelompok psikososial terhadap kelompok psikoklinis dalam penanganan korban bencana, karena mereka dianggap tidak mempertimbangkan aspek psikologis. Penelitian ini dilakukan dengan menggunakan metode kualitatif dengan pendekatan psikologis. Hasil penelitian ini selain bicara tentang pentingnya aspek psikologis dalam menangani korban bencana alam, juga menyatakan bahwa dalam melakukan layanan konseling terhadap korban bencana diperlukan perencanaan matang dan perlunya empati, ketegasan fleksibilitas antara tim dengan korban. Terakhir penelitian Endah Nawangsih, (2014), Play Therapy Untuk Anak-anak Korban Bencana Alam yang Mengalami Trauma (Post Traumatic Stress Disorder) Penelitian ini dilakukan dengan pendekatan kualitatif deskriptif. Hasil penelitian 
menyatakan bahwa konseling terhadap anak korban bencana dilakukan dengan tiga tahapan, yaitu 1) perhatian orang tua, 2) membuat kesan mendalam anak terhadap orang tuanya, 3) membuat permainan dan mengulangnya sebagai wujud stimulasi. Kajian ini lebih dekat dengan penelitian yang dilakukan. Perbedaannya terletak pada aspek teori tentang PTSD dan dakwah. Lingkup perbedaan ini yang nantinya justru akan melengkapi pendekatan dalam menangani anak-anak korban bencana alam.

Menengarai penelitian terdahulu, maka menggabungkan metode penanganan korban bencana dengan metode dakwah menjadi sebuah kebutuhan urgen yang tidak dapat diabaikan begitu saja. Pelaku dan ilmuan dakwah dituntut mampu mendapatkan metode yang sesuai dalam berdakwah terhadap anak-anak korban bencana alam dengan berbagai kondisi yang dihadapinya. Anak-anak korban bencana alam dikaji dengan seksama terkait dengan kondisi psikologis dan pemahamannya tentang perlunya "berdamai" dengan kondisi yang dihadapinya, termasuk hal-hal yang perlu untuk dilakukan dalam situasi bencana. Kematangan dan stabilitas psikologis anak merupakan sebuah target yang ingin dicapai dalam kajian tentang dakwah bi al lu'bah ini.

Terminologi dakwah bi al-lu'bah bisa diartikan sebagai dakwah yang dilakukan dengan permainan. Term ini bisa dikatakan sebagai "hal baru" dalam dunia dakwah. Dakwah dengan menggunakan media permainan sangat sulit dicari dalam referensi ilmu dakwah. Sejauh pengamatan peneliti, kajian ini belum banyak dikaji. Alasan mengapa hal ini terhadi juga belum dapat peneliti dapatkan secara jelas. Padahal di satu sisi, dakwah harus berubah dalam situasi dan kondisi mad'u. Perbedaan kondisi mad'u ini penting untuk didekati dengan metode dan media dakwah yang memang betul-betul keberadaannya dinantikan oleh mad'u. Mad'u harus menjadi obyek yang "dipuaskan" dalam dakwah yang dilakukan, bukan hanya obyek yang "harus" menerima materi yang didakwahkan oleh seorang da'i.

Dakwah bukan semata dilakukan kepada orang dewasa dalam situasi normal, tanpa kendala yang berarti. Namun, dakwah juga harus diberikan kepada mad'u dalam situasi yang tidak normal. Dalam situasi normal, menjalankan dakwah tidak membutuhkan treatment khusus, sementara dakwah dalam situasi yang tidak normal sangatlah membutuhkan piranti atau tools yang berbeda. Untuk itu menyiapkan dakwah dalam situasi tidak normal tersebut merupakan sebuah kebutuhan bagi da'i yang menjalankannya, lebih-lebih dalam hal anak sebagai mad'u dalam situasi tidak norma (korban bencana).

Dalam penelitian yang dilakukan, peneliti berharap kajian tentang dakwah dengan permainan ini mampu menghasilkan sebuah tawaran metodologis yang dapat dijadikan sebagai tambahan referensi bagi seorang da'i yang akan berdakwah kepada anak-anak korban bencana alam. Pelaksanaan metode dakwah dalam berbagai pembagiannya masih menyisakan permasalahan baik dari sisi internal (da'i) maupun eksternal (mad'u). Untuk itu melengkapi metodologi dakwah ini juga sebuah kebutuhan yang penting, mengingat bahwa kondisi mad'u selalu berubah, dengan dinamika yang mengelilinginya. Berangkat dari kenyataan ini, maka penelitian dengan judul "Metode Dakwah Bi al-Lu'bah sebagai Trauma Healing Anak Korban Bencana Alam" mempunyai nilai dan fungsi yang jelas bagi kesempurnaan kajian dakwah secara metodologis, termasuk untuk tawaran penyelesaian problematika sekaligus sebagai pengembangan ilmu dakwah dalam kancah khazanah kajian keislaman. Dari latarbelakang di atas, diketahui bahwa masih banyak persoalan yang menyangkut dakwah terhadap anak. Artikel ini berusaha mengungkap permasalahan bagaimana metode dakwah bagi anak korban bencana alam? dan bagaimana reformulasi metode dakwah bi al-lu'bah (melalui permainan) bagi anak-anak korban bencana alam? 


\section{Dakwah Bi-Al Lu'bah dan Anak Korban Bencana Alam}

Kata dakwah telah menjadi salah satu kosa kata bahasa Indonesia, yang berarti mengajak (menyeru) untuk mempelajari dan mengamalkan ajaran Islam.(Depdikbud, 1990: 181) Abu Bakar Zakaria berpendapat bahwa dakwah ialah usaha para ulama dan orang yang memiliki pengetahuan tentang agama (Islam) dengan memberi pengajaran kepada masyarakat akan hal-hal yang dapat menyadarkan mereka terhadap urusan keagamaan dan keduniaannya sesuai dengan kemampuan yang dimiliki.(Zakaria, tt: 21). Zakaria menyoroti dakwah dalam prakteknya lebih diarahkan pada aspek agama. Sementara, menurut Bachtiar (1997: 31), dakwah adalah proses atau upaya untuk mengubah kondisi menuju situasi yang lebih baik sesuai ajaran Islam. Bachtiar tidak membatasi dakwah dalam aspek agama saja, melainkan lebih menekankan pada perubahan kondisi masyarakat menuju hal yang lebih baik.

Perbedaan perspektif terkait definisi dakwah di atas, mengindikasikan kata kunci yang perlu untuk diungkap, yaitu tujuan dakwah. Tujuan dakwah sebagaimana sejatinya merupakan suatu usaha membina masyarakat agar terjadi perubahan dalam diri mereka, berkelakuan baik, dapat bersifat adil, baik dalam masalah pribadi maupun keluarga serta masyarakat, sehingga terjadi perubahan dari paradigma way of thinking yang diajarkan oleh Islam menuju perubahan way of life atau cara mereka dalam menjalankan hidupnya. Perubahan tersebutlah yang merupakan esensi yang diharapkan dari tujuan dakwah.(Sulthon, 2015: 4-5). Dengan demikian kata kunci yang dikedepankan dalam dakwah adalah merealisasikan tujuan untuk kebaikan umat.

Kebaikan umat tersebut dijadikan sebagai indikator utama yang keberadaannya memang diperhitungkan dalam pelaksanaan dakwah. Dalam menggapai hal ini dibutuhakn banyak hal yang melingkupinya. Semua hal dikerahkan demi kesuksesan seseorang dalam berdakwah. Boleh dikatakan bahwa perubahan mad'u dari hal yang "kurang baik" menjadi "lebih baik" merupakan sebuah tantangan yang terkandung dalam kegiatan dakwah. Melibatkan semua unsur dakwah dan menyelaraskan satu dengan lainnya merupakan "kewajiban" seorang da'i. Akselerasi unsur dakwah tersebut mutlak dilakukan, karena masing-masing mempunyai peran tersendiri untuk kesempurnaan kegiatan dakwah. Adapun Unsur-unsur dakwah adalah da'i (subyek dakwah), mad'u (obyek dakwah), maadah (materi), thoriqah (metode) dan wasilah (media).(Bahtiar, 1997: 31-35). Kelima unsur tersebut merupakan komponen yang tidak dapat dipisahkan antar satu dengan lainnya. Masing-masing mempunyai peran dalam menyempurnakan kegiatan dakwah. Berbagai pertimbangan yang diberikan dari unsur-unsur ini menjadikan dakwah berdaya guna untuk orang-orang yang terlibat di dalamnya.

Dalam rangka mengimplementasikan dan mengkomparasikan pemahaman antara ilmu dakwah dan ilmu lainnya, maka dibutuhkan semangat unity of sciences, yang pada akhirnya menjadikan ilmu dakwah sebagai sebuah rumpun ilmu keislaman yang dapat mengakomodir kemauan masyarakat. Upaya unity of sciencies dilakukan dengan mensinergikan ilmu-ilmu modern dalam bingkai transendensi dan perkembangan pemikiran dalam Islam. (Yusriyah, 2015: 401). Hal ini diyakini sebagai penyatuan yang dijadikan sebagai upaya penggambaran adanya unity of godhead yang akhirnya akan menghasilkan unity of creation atau kesatuan penciptaan. Upaya kesatuan penciptaan merupakan sesuatu yang dibutuhkan sebagai bagian dari pengembangan keilmuan dakwah, dimana keberadaannya selalu dituntut untuk berkembang, seiring dengan perkembangan masyarakat (mad'u). 
Mad'u merupakan obyek dakwah yang masing-masing mempunyai persoalan yang berbeda. Dari perbedaan kondisi mad'u ini mengindikasikan keharusan untuk melakukan dakwah dalam kondisi yang dialami oleh mad'u, sehingga dakwah diterima secara positif. Sebagai contoh, dalam situasi mad'u merupakan orang miskin, maka da'i diminta untuk tidak menyampaikan materi tentang zakat, infak dan shodaqah. Yang mereka butuhkan bukan untuk menambah beban yang dihinggapinya, namun lebih pada motivasi dan sikap optimis menghadapi kehidupannya, sehingga mereka terbebas dari belenggu kemiskinan dan menjadikan dirinya mampu untuk melaksanakan ibadah dan mempunyai "daya beli" yang tinggi sesuai kebutuhan mereka.

Dalam kondisi demikian dibutuhkan pengembangan metodologi sebagai respon atas kondisi yang dihadapi mad'u. Respon tersebut merupakan salah satu ukuran yang dapat dijadikan sebagai penilaian terhadap kinerja dakwah yang dilaksanakan. dari sini mungkin dapat diajukan sebuah logika pemikiran, "semakin sesuai metode dakwah yang dipilih dan digunakan, maka semakin tinggi tingkat keberhasilan dakwah". Untuk itu mengkaji dan mengembangkan metode dakwah merupakan sebuah keharusan bagi para ahli yang terlibat dalam pengembangan dakwah.

Sebagaimana diungkapkan di atas, dakwah bi al-lu'bah merupakan terminologi "baru" dalam kancah keilmuan dakwah. Dilihat dari artinya, dakwah merupakan kegiatan mengajak, sebagaimana telah digambarkan dalam pembahasan di atas. Konsep mengajak diarahkan pada perbaikan diri manusia sesuai dengan ajaran Islam, sehingga dirinya menjadi umat yang sesuai dengan yang diharapkan oleh Allah dalam al Qur'an dan hadits. Kata bi dalam bahasa Arab merupakan preposisi yang artinya dengan. (Pusat Bahasa Arab Lisan Mulia, 2017). Kata al lu'bah merupakan kata serapan dari kata laiba.(ukhtiuci.blogspot) yang berarti permainan. Kata bermain menurut Kamus Besar Bahasa Indonesia merupakan sekumpulan atau gabungan yang jumlahnya lebih dari satu.(Pusat Pembnaan Bahasa, 2010: 278) Menurut Dworetsky (dalam Muslichatun, 2004: 2-3) bermain merupakan kegiatan yang memberikan kesenangan untuk kegiatan itu sendiri, yang lebih menekankan cara daripada hasil yang diperoleh dalam kegiatan yang dilakukan. Sedangkan menurut Dearden bermain merupakan kegiatan non serius dan segala yang ada dalam permainan itu dapat memberikan kepuasan pada anak.

Kembali pada definisi dakwah bi al-lu'bah memberikan makna dakwah dengan permainan. Maksudnya bahwa dakwah yang dilaksanakan dikemas dalam bentuk permainan-permainan. Permainan direncanakan sebelum kegiatan dakwah dilakukan. Permainan yang diberikan mempunyai materi dan nilai dakwah, sehingga dengan metode ini diharapkan dapat memberi masukan tentang materi-materi keislaman yang telah dipersiapakan oleh da'i. Materi dakwah dalam permainan ini disusun sesuai dengan kebutuhan mad'u terhadap materi-materi dakwah itu sendiri. Permainan yang ada dapat diambil dari praktek permainan keeharian anak, termasuk menggunakan media permainan yang "digemari" oleh anak-anak dalam masa usianya. Dengan dakwah yang dikemas dalam wujud permainan tersebut, diharapkan anak-anak mendapatkan kepuasan, sehingga dengan kepuasan tersebut anak akan mengulang-ulang permainan yang dilakukannya. Walhasil anak selalu dapat mencerna dakwah yang diberikan oleh da'i.

Ayat al-qur'an sebagai sumber rujukan dalam penggunaan metode ini terdapat pada al-qur'an surat al an'am (6) ayat 32 yang artinya: "dan kehidupan dunia ini, selain dari permainan dan senda gurau belaka..." Juga dalam al qur'an surat al-Ankabut (29) ayat 32 "dan tiadalah kehidupan dunia ini, selain dari permainan dan senda gurau belaka..." Dalam tafsir dikatakan bahwa kata laibun (permainan) didahulukan, karena dunia permainan identik terjadi pada masa kecil. Sedangkan kata lahwun (senda gurau) diakhirkan karena dipakai untuk menunjukkan masa remaja atau dewasa 
yang identik dengan gaya hidup foya-foya dan banyak menyia-nyiakan waktu.(bincangsyariah.com). Keterangan di atas mengasumsikan bahwa permainan merupakan hal-hal yang dibutuhkan anak-anak, sedangkan senda gurau lebih kental dengan anak usia remaja atau bahkan dewasa.

Batasan anak dan dewasa ini kemudian harus diperhatikan dalam kancah keberadaan kondisi psikologisnya. Secara psikologis, anak dan dewasa mempunyai perbedaan dalam cara pandang terhadap sesuatu. Dalam teori Piaget (1896-1980) dikatakan bahwa anak merupakan masa tumbuh kembang, dimana pada tahapan ini dirinya sering membuat kesalahan yang sama dan secara konsisten dan berulangulang. Hal ini merupakan alamiah karena pengalaman fisik dan interaksinya dengan obyek - obyek yang terakumulasi (Piaget dan Inhelder, 2010: 21-22). Anak akan mencerna lingkungan sekitarnya setelah "melakukan kesalahan", sehingga dirinya berusaha untuk memahami segala sesuatu dengan nalar pikirannya. Nalar pikir anak lebih pada permainan, sehingga dengannya dia mampu untuk memahami hal-hal yang dibutuhkannya.

Sementara orang dewasa cenderung berbeda dengan anak dalam merespon lingkungan sekitarnya, dimana dirinya berusaha untuk melihat lingkungan dengan kacamata pandang pengalaman dan nalar yang telah berkembang. Orang dewasa cenderung mampu membedakan sesuatu dan tidak mengulang kesalahan seperti pada masa kanak-kanak. Dalam masa dewasa, manusia juga telah menggunakan nalar batinnya dalam merespon segala sesuatu yang melingkupinya. Pertautan antara nalar dan hatinya inilah kemudian mampu membuat dirinya bijaksana.

Kembali pada pembahasan tentang makna kata laibun. Kata laibun juga terdapat dalam hadits Nabi yang diriwayatkan dari Abu Hurairah r.a; "para sahabat bertanya: "Wahai Rasulullah Apakah anda suka bergurau kepada kami, Beliau bersabda: Benar!, hanya saja apa yang kukatakan tidak lain hanyalah kebenaran" (Dahlan dkk, 1995: 188). Hadits ini menginformasikan bahwa Rasulullah SAW juga mempunyai fase kehidupan sama dengan manusia lainnya. Beliau juga membutuhkan permainan, bahkan gurauan. Namun, lagi-lagi memang terdapat perbedaan antara permainan dan gurauan orang biasa dengan beliau.

Hal terpenting yang dapat diambil dari hadits ini adalah kenyataan bahwa permainan bagi anak-anak pada masanya merupakan sunnatullah. Selain itu juga adanya realitas bahwa apapun yang terjadi permainan dalam kehidupan dunia ini merupakan sebuah kebutuhan manusia yang tidak dapat dihindarkan. Terbukti sejak kecil manusia tidak dapat dilepaskan dari permainan, baik permainan berbentuk "mainan" maupun permainan-permainan yang mendatangkan kegembiraan hati. Dengan kata lain permainan merupakan sebuah kebutuhan manusia, khususnya anak-anak dalam mengisi kehidupannya. Ini menjadi penting maknanya, karena dengan permainan tersebut dirinya menemukan kebahagiaan, sekalipun kebahagiaan sesaat dan semu (apabila dipikir lebih mendalam).

Sebagai sebuah kebutuhan anak-anak, permainan selalu dikemas menarik sesuai dengan kebutuhan anak dan perkembangan masa yang dihadapinya. Anak-anak pada masa tahun 1970-an berbeda bentuk permainan yang disukainya dengan anak-anak pada 10-20 tahun kemudian. Bahkan sekarang permainan anak juga berbeda dengan sebelumnya. Artinya, bahwa ketertarikan anak terhadap permainan tertentu harus dipahami seseorang yang berkutat pada persoalan anak, termasuk da'i yang mempunyai segmentasi mad'u anak-anak. Permainan yang dihadirkan harus sesuai dengan perkembangan teknologi, daya nalar anak pada masanya.

Dalam pelaksanaan dakwah, penggunaan metode bersifat pilihan. Artinya, seorang da'i dapat memilih metode sesuai dengan kebutuhannya. Da'i harus memperhatikan kondisi mad'unya. Ragam metode dakwah yang ada dikemas dalam bentuk tertentu, yang pada akhirnya mampu diterima sebagai hal baik yang dapat 
mempengaruhi kondisi mad'u. Dengan metode yang digunakan, seorang da'i akan memberikan kontribusi maksimal dalam proses penerimaan materi dakwah. Hal ini sebenarnya yang menjadi target pemilihan metode dalam dakwah.

Dengan metode yang sesuai, seorang da'i dapat berinteraksi dan dekat terhadap mad'unya. Dalam aplikasi metode dakwah bi al lu'bah ini, seorang da'i berkewajiban mendekatkan dirinya dengan anak-anak yang menjadi mad'unya. Permainan yang ada merupakan media yang digunakan untuk mengajak mad'u mengikuti materi dakwah yang disampaikan. Memang tidak semua da'i dapat memberikan permainan yang diharapkan oleh mad'u, dan tidak semua mad'u mau untuk diajak bermain. Namun, dengan pengemasan permainan yang cantik diharapkan ada ketertarikan awal dari mad'u untuk mengikuti permainan sekaligus mengikuti dakwah yang dilaksanakan. Bermodal ketertarikan mad'u inilah kemudian dakwah yang akan dilakukan akan berdayaguna dan menuai hasil yang diinginkan.

Dakwah bi al lu'bah sebenarnya mudah dilakukan, tergantung pada pengemasan, yang menurut Kotler dan Keller merupakan kegiatan merancang dan memproduksi wadah atau bungkus sebuah produk (Kotler dan Keller, 2009: 27). Mengacu pada pendapat ini maka, pengemasan permainan dalam kegiatan dakwah menjadi sesuatu yang menarik untuk dapat dijadikan sebagai pilihan bagi da'i yang menggunakan metode ini dalam dakwahnya. Dengan kemasan permainan yang menarik akan muncul ketertarikan mad'u untuk mengikuti kegiatan ini. Dengan demikian, kegiatan dakwah yang dibungkus dengan permainan dapat memberikan kontribusi positif dalam keberhasilan dakwah. Persoalan kemudian adalah bagaimana cara menggunakan metode dakwah bi al-lu'bah ini?

Penggunaan metode dakwah bi al lu'bah ini dapat dilaksanakan dengan beberapa cara, yaitu;

Pertama, penyusupan materi dakwah pada permainan yang ada. Menyusupkan (inviltrasi) pada permainan yang lazim dilakukan oleh mad'u. Sebagai contoh adalah permainan anak-anak seperti, Go Back to Door. Permainan ini mensyarakatkan seseorang untuk masuk ke arah yang dituju melalui pintu yang dijaga oleh lawannya. Penyusupan yang dapat dilakukan adalah dengan mengucapkan salam (assalamualaikum) ketika melewati "pintu" yang ada. Permainan lain, dengan media olah raga. Contohnya; sepak bola, pada saat sebelum permainan dilakukan pemain dapat diberi ceramah akan pentingnya menjaga sportifitas, tidak berbuat curang, ajakan untuk doa bersama sebelum permainan berlangsung dan sebagainya.

Kedua, membuat permainan dakwah, Membuat permainan dakwah dapat dilakukan dengan berbagai cara. Misalnya tebak-tebakan dengan materi dakwah; siapakah sahabat Nabi Muhammad SAW yang selalu mejadi bemper dalam kegiatan Nabi? Siapa yang mengetahui rukun Islam yang ke dua? Dan sebagainya. Dengan permainan ini diawali dengan pemberian materi, untuk kemudian dibuat flash back, sehingga dapat dijadikan sebagai upaya menguji ingatan mad'u (pelaku permainan).

Ketiga, membuat syair tentang materi dakwah melalui lagu-lagu populer yang dapat mudah diingat. Menyusun syair untuk dinisbatkan dengan lagu-lagu populer merupakan salah satu tugas da'i agar mad'u selalu mengingat materi yang diberikan. Dengan syair dan nada irama yang "familiar" diharapkan memori mad'u mampu terbawa ke dalam syair-syair sebagai materi dakwah. Sebagai contoh adalah lagu lirilir yang sampai sekarang masih digunakan oleh para da'i untuk memberi peringatan untuk beribadah kepada Allah. Dalam kancah permainan misalnya mengganti syair lagu "Balonku Ada Lima" dengan "Rukun Islam yang 5, Syahadat, sholat, zakat...Puasa, Naik Haji itulah Syariatku. Salah satu yang bolong ... DOR ... hatiku sangat Kacau, Rukunku tinggal 4 kupegang erat-erat. Metode ini telah banyak dilakukan bagi kalangan pendidikan anak usia dini, untuk menumbuhkan kecintaan pada ajaran Islam. 
Dengan ketiga cara untuk melaksanakan dakwah melalui metode permainan ini diharapkan keterpengaruhan mad'u kepada da'i diawali dengan rasa senangnya terhadap permainan. setelah itu kemudian materi dan nilai dakwah dimasukkan untuk dapat dimengerti, dipahami dan diamalkan oleh mad'u. Dengan demikian, seorang mad'u tidak menyadari bahwa dirinya telah mendapatkan "kesenangan" melalui dakwah yang dikemas dalam bentuk permainan. Ini dibutuhkan untuk kesempurnaan dakwah bagi mad'u yang notabene mereka dalam kondisi tertentu. Dakwah bi al'lu'bah tidak hanya sekedar adopsi dari permainan yang telah ada, lebih dari itu adalah untuk mendapatkan bentukan baru dalam kancah dakwah.

Dalam konteks mendapatkan bentukan baru permainan berbasis dakwah ini dibutuhkan upaya para da'i untuk memperkaya materi permainan anak. Keterpaduan antara materi dakwah dan permainan yang diadopsi seorang da'i menjadi kata kunci kinerja dakwah bi al-lu'bah ini. Keterpaduan antara materi dakwah dengan permainan yang dibentuk merupakan bagian yang tidak dapat dipisahkan. Sebuah asumsi yang dapat dikemukakan adalah bahwa apabila seorang da'i mampu membentuk permainan untuk anak dan mengisi dengan materi dakwah yang sesuai berdampak pada keberhasilan dakwah yang diharapkan, tentunya juga sesuai dengan kondisi mad'unya.

Dari pembahasan tentang pentingnya sinergitas antara materi dakwah dan bentuk permainan ini akan melahirkan unsur-unsur yang dibutuhkan dalam kinerja dakwah bi al-lu'bah. Lebih dari itu, dakwah bi al lu'bah akan menghasilkan sebuah tatanan metodologis yang semuanya bergantung satu unsur dengan lainnya. Masingmasing unsur saling melengkapi dan semuanya diarahkan pada keberhasilan penggunaan metode ini.

\section{Dinamika Dakwah dan Trauma Healing Terhadap Anak-anak Korban Bencana Alam}

Menjalankan dakwah dilakukan dalam situasi dan kondisi normal tidak akan menimbulkan persoalan baru. Sebaliknya melaksanakan dakwah dalam kondisi yang tidak sewajarnya akan memunculkan persoalan baru dalam berbagai sisi. Dakwah mempunyai tujuan untuk kemaslahatan umat dalam berbagai segmentasinya.Dalam situasi dan kondisi bencana alam, dakwah biasanya kurang diminati oleh korban (mad'u). Mengingat yang dibutuhkan mereka sesaat setelah terjadinya bencana adalah materi (rumah, kendaraan, harta benda). Sekilas fenomena ini merupakan kondisi yang tidak dapat terelakkan. Namun, apabila dikaji lebih mendalam, yang dibutuhkan korban bencana adalah kondisi psikologis yang stabil dalam menerima kenyataan akan kehilangan yang dialaminya. Mereka mengalami penurunan psikologis yang membutuhkan sentuhan "imani" untuk menguatkan keberadaan psikisnya. Setelah keadaan psikis korban bencana stabil, maka dirinya mampu untuk melakukan reorientasi terhadap kehidupannya ke depan.

Dalam hal dakwah yang dilakukan saat bencana alam, biasanya yang disentuh adalah orang tua dalam situasi tertentu, seperti saat menjalankan sholat di masjid, istighosah bersama. Dakwah yang dilakukan belum merambah langsung pada korban bencana yang memang dirinya membutuhkan sentuhan dalam banyak hal. Kenyataan ini merupakan kelemahan bersama, yang harus dicari pemecahannya. Konsepsi dakwah dengan nilai luhur yang termanifestasikan dalam materi dakwah tidak tersalurkan pada yang membutuhkan. Terdapat beberapa penelitian yang inten untuk bicara cara berdakwah kepada korban bencana alam. Namun belum menyentuh pada prosedur baku yang kemudian dapat dijadikan sebagai cara dalam berdakwah kepada para korban bencana alam tersebut.(Wihartati, 2014: 284). Kebutuhan akan tata cara berdakwah dikalangan korban merupakan sebuah kebutuhan, yang dapat diadopsi oleh para da'i dalam menjalankan kegiatan 
kemanusiaan ini. pengembangan terhadap metode dakwah ini merupakan sebuah hal penting yang keberadaannya sangat dinantikan oleh semua stakeholder dalam dakwah.

Secara umum, pengalaman bencana dapat menyebabkan beberapa hal, yaitu 1) kejadian yang berada di luar kontrol personal yang mengalaminya, 2) menyebabkan kematian atau luka fisik yang parah dan 3) menimbulkan ketakutan berkepanjangan yang pada akhirnya menyebabkan seseorang menjadi tertutup dan tidak mau berinteraksi dengan lingkungannya.(Wihartati, 2014: 285) Ketiga hal tersebut kemudian dapat menyebabkan banyak faktor lainnya yang kemudian menjadi sebuah "momok" bagi manusia yang terkena dampak bencana alam.

Trauma, sebagai salah satu bentuk akibat bencana alam merupakan pengalaman yang menyakitkan bagi korban atau seseorang. Individu yang mengalami trauma berusaha menghindari kejadian atau situasi yang menimbulkan trauma. Tanda trauma dapat dilihat dalam beberapa hal, antara lain 1) Melemahnya fisik seseorang dengan munculnya keadaan lesu, muntah dan sejenisnya, 2) Minimnya aspek kognitif yang ditandai dengan kebingungan dan berkurangnya daya konsentrasi, 3) Terganggunya emosional dengan ditandai kegelisahan yang tak kunjung reda, dan 4) kecenderungan untuk menarik diri dari lingkungan sosial korban (Widyastuti, 2019:.101-102).

Lebih lanjut, dengan pengalaman trauma yang dialami korban bencana secara berkepanjangan, akan berakibat pada gangguan stress (Normalasari, 2009: 7). Selain daripada itu, trauma juga berakibat pada beberapa hal antara lain; mempengaruhi aspek kepribadian, mempengaruhi cara pandang seseorang, menghancurkan kehendak membangun masa depan dan mengoyakkan keyakinan dan keimanan serta memperkuat kemarahan dan dendam (Kusumaningrum dkk, 2015: 10). Kenyataan akan bahaya trauma ini mengindikasikan bahwa keberadaannya tidak boleh menghinggapi seseorang, karena memberikan dampak negatif.

Trauma healing merupakan terminologi yang tidak asing lagi dikalangan pemerhati dibidang bencana, khususnya bidang ilmu psikologi. Keberadaannya merupakan sebuah usaha untuk memberikan terapi kepada para korban bencana agar tidak mengalami trauma atas bencana yang dialaminya. Pengertian trauma healing merupakan metode pemulihan atau penyembuhan pada gangguan psikologis yang dialami seseorang, karena lemahnya ketahanan fungsi-fungsi mental (Mendato, 2010: 5). Trauma healing merupakan tindakan yang dilakukan oleh seseorang untuk menghilangkan gangguan psikologis yang diakibatkan oleh gangguan mental (syok atau trauma). Trauma healing berusaha mengurai persoalan yang dihadapi seseorang agar menemukan solusi yang lebih baik. Dengan trauma healing, seseorang akan mendapatkan manfaat antara lain; kebahagiaan, ketenangan dan ketentraman batin, mengurangi beban pikiran dan responsif terhadap hal-hal yang terjadi di lingkungan sosialnya.

Trauma healing dilakukan dengan beberapa metode, yaitu: 1) terapi aktivitas kelompok, merupakan upaya untuk menyamakan persepsi dalam kelompok kehidupan masyarakat, 2) Terapi Memasak, yaitu pemberian bimbingan melalui memasak dalam menciptakan interaksi bersama, 3) Relaksasi, mengarahkan masyarakat untuk memberikan ketenangan dari masalah yang dihadapi, 4) terapi permainan, menggunakan alat bermain dalam mengurangi beban pikiran, dan 5) terapi spiritual, biasanya disebut sebagai SELF (Spiritual Emotional Freedom Technique) (Slegal, 2003: 23-25). Kelima bentuk metode trauma healing di atas merupakan sebuah upaya yang diperuntukkan untuk mengurangi trauma yang disandang seseorang yang mengalami gangguan kejiwaan. Korban bencana merupakan salah satu segmen yang mengalami gangguan tersebut. Dirinya membutuhkan "hiburan" agar tidak terbelenggu pada kondisi depresi tersebut. 
Melihat beberapa bentuk trauma healing ini dapat dikatakan bahwa hal ini mempunyai korealasi dan benang merah dengan dakwah.

Dakwah sebagai upaya untuk merubah kondisi seseorang menjadi lebih baik secara rohani dan jasmani menjadi penting untuk saling "bertukar" konsep dengan tata cara trauma healing. Keduanya dapat bersinergi dalam menjadikan sasaran kegiatannya melalui teknik masing-masing. Bahkan menurut hemat peneliti, terdapat ruh masing-masing konsep dalam aplikasi kegiatannya. Teknik trauma healing, khususnya SELF dan relaksasi serta permainan dapat dijadikan sebagai salah satu metode dakwah itu sendiri. Penggabungan teknik trauma healing dan dakwah secara metodologis menjadi satu kesatuan yang tidak dapat terpisahkan. Label yang ada dalam trauma healing dan dakwah perlu diejawantahkan sebagai perwujudan afiliasi yang mampu untuk merubah kondisi obyek masyarakat. Trauma healing memandang penting untuk merubah kondisi masyarakat dengan materi-materi keagamaan yang ada dalam dakwah. Selanjutnya, dakwah harus mampu memberikan nilai tertentu dalam kegiatannya melalui media permainan, memasak atau bahkan kelompok diskusi masyarakat yang dalam bahasa trauma healing disebut sebagai aksi kelompok.

Dengan upaya penggabungan tersebut jelas akan memberikan nilai lebih demi keberhasilan trauma healing maupun dakwah itu sendiri. Kesimpulan sementara dapat dikatakan bahwa dakwah dapat dijadikan sebagai trauma healing. Persolan yang ada sekarang adalah bagaimana menyusun materi dakwah melalui teknik trauma healing, dengan segmentasi mad'u anak-anak korban bencana alam? Mungkinkah trauma healing saja cukup? Atau bagaimana memunculkan metode dakwah yang diarahkan pada penggunaan teknik trauma healing dalam menyasar anak-anak korban bencana alam tersebut? Menjawab hal ini kiranya penting untuk mendefinisikan kembali tentang anak dan ruang lingkup yang terdapat dalam dirinya.

Dalam kamus bahasa Indonesia, anak dimaknai sebagai manusia yang masih kecil atau belum dewasa (Poerwadarminta, 1997: 25). Sedangkan menurut Wikipedia, anak adalah seorang laki-laki atau perempuan yang belum dewasa atau belum mengalami pubertas (wikipedia.org). Dari dua definisi di atas dapat diketahui bahwa sebenarnya anak merupakan fase terkecil kedua (setelah bayi) dari pertumbuhan manusia. Hal ini senada dengan pendapat Hurlock (1980) manusia berkembang melalui beberapa tahapan yang berlangsung secara berurutan, terus menerus dan dalam tempo perkembangan tertentu Hurlock, 1999: 3). Dengan demikian, anak merupakan tahapan setelah bayi dan sebelum remaja.

Lebih jelas lagi terkait dengan definisi anak adalah sesuai dengan Pasal 1 (ayat) 1 UU No. 23 tahun 2002 tentang perlindungan anak. Anak didefinisikan sebagai seseorang yang belum berusia 18 tahun, termasuk anak yang masih dalam kandungan. Dari pasal 1 UU No 23/2002 ini semakin jelas batasan perlakuan terhadap usia anak. Dalam kehidupannya, anak-anak mempunyai hak-hak primer, yaitu hak hidup, perlindungan dan tumbuh kembang. Hak lainnya antara lain hak hak asuh anak, perwalian yang diperlukan karena ketidakmampuan orang tua berhubungan dengan hukum, pengangkatan anak yang sangat memperhatikan kepentingan anak, serta penyelenggaraan perlindungan dalam hal agama, kesehatan, pendidikan, sosial, pendidikan, kesehatan, perlindungan khusus, bahkan hak bermain (Ghoni, 2017: 25).

Anak korban bencana alam berada dalam situasi yang tidak normal. Biasanya, anak dalam sebagai korban gempa mengalami beberapa penyakit antara lain trauma. Trauma didefinisikan sebagai suatu pengalaman mental yang sangat menyakitkan, karena melampui batas kenormalan individu yang menanggungnya dan korban tidak berdaya serta dihinggapi ketakutan (Durand dan Barlow, 2006: 201). Kondisi ini memerlukan penanganan yang serius, karena apabila dibiarkan akan menjadi 
penyakit yang lebih serius lagi, seperti gangguan jiwa bahkan sampai pada kegilaan. Tentunya efek negatif dari bencana alam merupakan sesuatu yang dihindari dari anak-anak sebagai generasi masa depan.

Dalam upaya melindungi anak sebagai korban bencana alam ini, diperlukan sebuah upaya untuk melatih kekuatan batin dan fisik anak dalam menghadapi musibah. Anak dengan dunianya tentu berbeda dengan kondisi orang dewasa. Mereka mempunyai naluri sebagai makhluk hidup yang beragam sebagai fitrah yang telah diberikan Allah SWT. Penanaman keimanan menjadi penting sebagai bekal untuk menghadapi kehidupan kelak. Mendidik anak melalui dakwah dalam kondisi yang dialami anak menjadi sebuah kepentingan yang perlu untuk selalu digaungkan. Dalam kondisi bencana, anak harus mengembangkan dirinya dengan nilai dan ajaran agama untuk memasuki kondisi yang berbeda dengan sebelum bencana tersebut ada. Pada tahap ini, seorang anak mulai belajar dengan lingkungan dan kondisi yang "baru". Dirinya tidak harus bergantung pada orang tua semata, melainkan mempunyai inisiatif untuk tetap survive dalam bencana alam yang dialaminya.

Memberikan pendidikan agama bagi anak melalui dakwah tidak menyisakan persoalan apabila dilakukan dalam situasi dan kondisi normal. Dalam situasi tidak normal, dimana anak tersebut terkendala dalam mentalnya, dibutuhkan pendekatan khusus yang mempu memberikan kepuasan dan kenyamanan diri dalam berinteraksi dengan lingkungan sekitarnya. Dalam hal anak terkena dampak bencana, maka teknik trauma healing dipandang perlu sebagai alternatif penyelesaian masalah pada mental anak ini. Selain itu dakwah juga dipandang mempunyai nilai strategis dalam "menyembuhkan" penyakit mental anak tersebut.

Dakwah bagi anak korban bencana alam, tentunya diarahkan pada kondisi yang dihadapi anak dalam berbagai sisi. Keberadaan anak dipandang sebagai sesuatu yang mempunyai nilai yang perlu untuk dikembangkan. Pendidikan yang dikemas dalam dakwah, teknik trauma healing yang diramu dengan dakwah dan treatmen lain menjadi sangat penting ketika dihadapkan pada anak korban bencana alam tersebut. Semuanya diarahkan apada pemenuhan kewajiban untuk menyelesaikan persoalan psikologis anak, sehingga dirinya menjadi nomal kembali, walaupun dalam situasi yang tidak normal dan tidak bersahabat baginya.

Fenomena ini merupakan PR besar bagi semua stakeholder yang terkait dengan dakwah terhadap anak. Dakwah harus mampu memformulasikan ide-ide dan nilai serta materinya untuk menyelesaikan persoalan ini. Apabila hal ini dilupakan, maka generasi penerus ini akan terjebak pada kenyataan bahwa dirinya akan masuk pada pandangan, dimana Allah SWT telah berlaku tidak adil terhadap dirinya, seiring dengan bencana alam yang menimpanya. Lebih riskan lagi apabila kemudian "garapan" dakwah ini tidak dilakukan akan dimanfaatkan "pihak lain" yang berkepentingan untuk mengalihkan agama anak ini. Kenyataan ini merupakan bagian dari hal yang tidak dapat terhindarkan.

Atas fenomena tersebut, upaya untuk menyelamatkan generasi bangsa ini dapat dilakukan dengan memberikan perhatian khusus pada anak korban bencana alam, khususnya mereka yang menyandang predikat trauma / disorder. Dakwah harus mempu memberikan nilai tawar dalam menyelesaikan persoalan di atas. Tentunya dakwah harus bersinergi dengan keilmuan lain yang dipandang mempunyai hubungan dengan persoalan anak dan trauma. Muatan nilai dan materi dakwah harus disesuaikan dengan kebutuhan anak, sehingga memberikan masukan positif dalam menyembuhkan trauma yang disandangnya.

Perlakuan dakwah terhadap anak korban bencana alam ini membutuhkan piranti yang lengkap sebagai bagian dalam menyelasaikan persolan trauma pada anak. Perombakan dan penyusunan unsur-unsur dakwah (da'i, materi, mad'u, metode, media dan effek) dalam menangani anak trauma merupakan sebuah 
kebutuhan mendesak yang dengannya dapat dijadikan sebagai ajang penyelesaian masalah ini. selain itu, dakwah harus mempu mengemas kegiatannya dengan nilainilai pendidikan untuk anak, sehingga dirinya mendapatkan tambahan masukan untuk dapat memberikan arti hidup yang sebenarnya. Singkat kata, upaya dakwah dengan menggunakan piranti yang dibutuhkan (konsep trauma healing, konsep pendidikan, konsep psikologi perkembangan anak dan lainnya) merupakan salah satu hal yang dapat dijadikan sebuah alternatif solusi dalam menangani anak korban bencana alam. Terapi permainan yang dikemas dalam kegiatan dakwah merupakan salah satu jawaban untuk dapat dijadikan sebagai solusi atasnya. Kata kunci lain yang dapat diutarakan adalah bahwa penggabungan antara teknik trauma healing dengan proses dakwah menjadi ruh dalam aplikasi dakwah bi al-lu'bah.

\section{Reformulasi Metode Dakwah Bi Al Lu'bah Bagi Anak Korban Bencana Alam}

Untuk menggambarkan benang merah antara trauma healing dengan dakwah, berikut ini akan dikaji berdasarkan filosufi konsepnya.

\begin{tabular}{|l|l|l|}
\hline \multicolumn{1}{|c|}{ Filsafat } & \multicolumn{1}{|c|}{ Dakwah } & \multicolumn{1}{c|}{ Trauma Healing } \\
\hline Epistemologi & Al-quran dan hadits & $\begin{array}{l}\text { Filsafat psikologi } \\
\text { (behaviorisme) }\end{array}$ \\
\hline Ontologi & Teologis - etis & $\begin{array}{l}\text { Pikiran dan kognisi } \\
\text { manusia }\end{array}$ \\
\hline Aksiologi & $\begin{array}{l}\text { Transformasi ajaran } \\
\text { Islam dalam amal } \\
\text { soleh dan } \\
\text { perwujudan } \\
\text { peradaban Islam }\end{array}$ & $\begin{array}{l}\text { Mengetahui kondisi } \\
\text { mental individu dan } \\
\text { membuat kestabilan } \\
\text { sikap dan perilaku }\end{array}$ \\
\hline
\end{tabular}

Tabel 1

Filosufi Trauma Healing dan Dakwah

Dari tabel di atas diketahui bahwa hubungan antara dakwah dan trauma healing secara filosufis ketemu pada aspek ontologis dan aksiologis. Dalam ranah ontologi dakwah (teologis-etis) dirinya merupakan sebuah upaya untuk mengembangkan konsep etis dalam kancah teologi islam. Konsep yang dikembangkan dalam dakwah merupakan penciptaan nilai-nilai etis atau dengan kata lain merubah individu atau masyarakat menuju tatanan yang lebih baik. Sementara ontologi trauma healing lebih pada kondisi dan hekekat pikiran dan kognisi manusia. Trauma healing merupakan bagian dari pencapaian kesesuaian pikiran manusia.

Dari aspek di atas, maka dasar hekekat dakwah dan trauma healing dapat dijadikan sebagai sebuah rumpun kegiatan untuk merubah manusia menjadi lebih baik. Hakekat keduanya merupakan kajian etis dan keberadaan etis itu sendiri tidak dapat dilepaskan dari pikiran dan kognisi manusia. Berangkat dari hal ini dapat diketahui bahwa titik temu secara ontologi antara dakwah dan trauma healing terletak pada muatan etis dan sikap serta perilaku manusia, yang dengannya perlu untuk dijadikan sebagai sandaran dalam kegiatannya.

Dakwah merupakan proses internalisasi (penghayatan), difusi (perpindahan), institusionalsasi dan transformasi agama Islam dengan konsep-konsep yang dijadikan sebagai materi dakwah. Secara ontologis diketahui bahwa kegiatan dakwah tertunya lebih ditekankan pada konsep etis berlandaskan pada konsep agama Islam. Sementara trauma healing menekankan pada cara pencapaian pikiran dan perilaku yang seimbang pada masing-masing individu dan kelompok tertentu.

Menggabungkan antara filsafat ontologi dakwah dan trauma healing dapat dilakukan dengan melihat hakekat atau keberadaan keduanya, baik secara teoritis 
maupun praktisnya. Praktisnya adalah mencapai nilai etis merupakan hubungan antara keduanya yang dapat dilaksanakan dengan menyusun orientasi tujuan. Orientasi tujuan dakwah dan trauma healing dengan mengedepankan ontologi keduanya menghasilkan sebuah tawaran penggabungan, yang dalam hal ini disebut sebagai bagian mencari titik temu.

Penggabungan antara dakwah dan trauma healing, secara metodologis praktis dapat dilihat dari tabel berikut ini;

\begin{tabular}{|l|l|}
\hline \multicolumn{1}{|c|}{ Trauma Healing } & \multicolumn{1}{c|}{ Metode Dakwah } \\
\hline Terapi aktivitas kelompok & Metode Jamaah \\
\hline Terapi Memasak & Metode bi al hal \\
\hline Relaksasi & Metode Muhasabah \\
\hline Terapi permainan & Metode Bi al lu'bah \\
\hline Terapi spiritual & Metode Irsyad \\
\hline
\end{tabular}

Tabel 2

Hubungan Metode Trauma Healing dan Metode Dakwah

Berangkat dari tabel di atas, diketahui bahwa sekilas tergambar adanya kesamaan praktis antara keduanya. Terapi aktivitas kelompok diartikan sebagai 1) terapi yang diupayakan oleh psikoterapis kepada kelompok pasien yang mengalami ganggunan kejiwaan, 2) dengan mengadakan hubungan yang erat antara psikoterapis dengan pasiennya, 3) dilakukan dengan cara musyawarah, 4) meningkatkan hubungan interpersonal untuk memperbaiki kondisi pasien dalam waktu yang bersamaan, dan 5) upaya yang dilakukan psikoterapis dalam kurun waktu tertentu untuk memicu keasadaran.(dosenpsikologi.com). Adapun metode jamaah merupakan salah satu cara dakwah yang dilakukan oleh seseorang (da'i) dengan cara bersamasama antara keduanya dalam menyelesaikan persolan yang dihadapi mad'u.

Hubungan antara kedua metode ini tergambar dari adanya proses dakwah dan trauma healing dengan menjadikan (psikoterapis - da'i) sebagai publik figurnya. Kepiawaian keduanya terletak pada pencapaian hubungan positif antara subyek dan obyeknya. Kata kunci utama antara dua metode ini adalah tentang cara menghubungakan antara keduanya yang dilandasi dengan kesadaran untuk bersama. Setelah keduanya mempunyai kesepahaman dan kesepakatan bersama, pada akhirnya subyek (psikoterapis - da'i) memberikan materi tentang hal-hal yang dapat mengembalikan obyek (korban bencana) pada kesadaran tentang kehidupan sebelum bencana terjadi.

\section{Formulasi Metode Dakwah bi al-lu'bah dengan Play Therapy}

Dalam melaksanakan dakwah bi al lu'bah, dapat diawali dengan pemberian motivasi. Motivasi adalah keadaan kejiwaan dan sikap mental manusia yang memberikan energi, mendorong kegiatan (moves), dan rnengarah atau rnenyalurkan perilaku kearah mencapai kebutuhan yang memberi kepuasan atau mengurangi ketidakseimbangan. Dalam pengertian lain, rnotivasi merupakan kegiatan yang mengakibatkan, menyalurkan, dan memelihara perilaku manusia Siswanto, 2007: 119). Tujuan motivasi berdasarkan pada definisi ini adalah mencapai kepuasan manusia. Umumnya, kepuasan manusia satu dengan lainnya bersifat sama dalam spektrum kehidupan yang sama pula. Misalnya, dalam pemenuhan hajat kehidupan, setiap manusia mendambakan kesehatan, kesejahteraan, kemakmuran, kesalihan dan sebagainya. Dalam hal kesuksesan, manusia menginginkan kesuksesan yang dapat mengantarkan dirinya pada citacita yang diidamkannya. 
Pemenuhan cita-cita merupakan parameter dalam kesuksesan seseorak memang memotivasi manusia lainnya. Berangkat dari cita-cita itulah kemudian dijadikan sebagai sandaran untuk merubah pemikiran sesorang. Dalam keadaan demikian, seorang motivator akan mengambil "kata kunci" yang diimpikan oleh seseorang, sehingga materi motivasinya dapat dijalankan oleh obyek motivasi. Seseorang akan terdorong oleh motivasi apabila hal tersebut dapat mengantarkan pada pemenuhan cita-citanya. Dengan demikian, motivasi merupakan istilah yang digunakan untuk menunjukkan sejumlah dorongan, keinginan, kebutuhan, dan kekuatan.

Memotivasi berarti tindakan dari seseorang yang ingin mempengaruhi orang lain untuk berperilaku (to behave) secara tertentu. Dalam konteks ini, maka motivasi menjelaskan suatu aktivitas manajemen (mengelola), atau sesuatu yang dilakukan seorang manajer untuk membujuk atau mempengaruhi bawahannya untuk bertindak secara organisatoris dengan cara tertentu untuk menghasilkan hasil-hasil yang efektif. Hasil motivasi tersebut merupakan segala sesuatu yang disepakati sebagai bagian dari target yang telah disepakati antara kedua belah pihak. Dengan demikian, dapatlah dikatakan bahwa motivasi tampak sebagai kebutuhan sekaligus sebagai pendorong yang dapat menggerakkan semua potensi, baik karyawan maupun sumber daya lainnya (Handoko, 2000: 215).

Menggerakkan seseorang menuju pada sasaran yang diinginkan merupakan sesuatu yang tidak mudah untuk dilakukan. Butuh banyak piranti dalam membantu terpenuhinya hal tersebut. Masing-masing piranti mempunyai nilai yang tidak dapat diabaikan begitu saja. Keterkaitan antar piranti merupakan sesuatu yang pasti adanya. dukungan masing-masing akan membantu pada tercapainya tujuan yang diidamakan. Semua hal ini berlaku tidak hanya dapal proses memotivasi seseorang, melainkan dalam banyak kegiatan seperti konseling, terapi, mengembangkan atau memberdayakan masyarakat, termasuk juga dakwah.

Dakwah sangat dibutuhkan masyarakat sebagai salah satu upaya untuk penyadaran diri, sekaligus sebagai upaya untuk merubah manusia dari kondisi yang negatif menjadi positif. Keberadaan dakwah ini merupakan sebuah kodrati manusia yang menganggap dirinya sebagai makhluk sosial. Sebagai makhluk sosial, dirinya membutuhkan peran dan kiprah manusia lainnya sebagai pelengkap kehidupan di dunia. Peran manusia lain dalam dakwah (da'i) dinantikan untuk merubah diri manusia lainnya (mad'u), baik dalam situasi biasa maupun luar biasa. Perlakuan da'i terhadap mad'u harus selaras dengan kondisi yang dihadapinya.

Dakwah terhadap anak merupakan upaya pendidikan agama yang dengannya akan merubah anak menjadi cikal pemimpin masa depan. Dengan dakwah terhadap anak, akan memberikan pembelajaran positif sekaligus sebagai pendorong atau motivasi dalam merespon kehidupan yang lebih baik. Tatapan masa depan yang baik, merupakan salah satu kata kunci yang diperlukan bagi anak. Tentunya hal ini harus diorientasikan pada keseimbangan antara persepektif dunia dan akherat. Keseimbangan keduanya akan mengantarkan anak pada kesalihan emosional maupun kesalihan spiritual.

Dakwah pada anak dalam situasi normal tidak menyisakan persoalan yang berarti, karena semuanya dapat dilaksanakan dalam situasi yang tidak ada kendala operasional. Sebaliknya dakwah terhadap anak dalam situasi yang tidak normal berimplikasi pada pemikiran lanjut yang diproyeksikan untuk pelaksanaan kegiatan dakwah. Peran da'i menjadi penting adanya untuk merealisasikan hal ini. Selain itu, untuk memberikan dakwah kepada anak dalam situasi tidak normal (bencana alam), peran keluarga menjadi penting adanya. 
Keluarga harus mampu memberikan perlindungan terhadap anak, jangan sampai kondisi bencana yang memperburuk kondisi keluarga justru menjadikan anak sebagai pelampiasan amarah bagi orang tuanya. Tidak dapat dipungkiri, kondisi bencana alam akan mengantarkan anak pada kondisi buruk baik fisik maupun psikisnya. Selain itu juga akan berdampak pada produktivitas anak di lingkungan sosialnya, baik sekitar rumah, bahkan di sekolah (Chomaria, 2012: 16).

Sebagai upaya untuk menjamin kondisi anak dalam situasi bencana alam tersebut, dibutuhkan dakwah yang sesuai dengan kondisi yang sedang dihadapi anak. Seorang da'i dituntut mampu memberikan materi dakwah yang sesuai dengan kebutuhannya. Pemenuhan kebutuhan anak menjadi target yang seharusnya dipenuhi, sehingga keseimbangan antara kebutuhan fisik dan psikis dapat terealisir. Ini membutuhkan kerja bersama seluruh stakeholder untuk merumuskan dakwah yang sesuai untuk anak-anak korban bencana alam.

Pada pembahasan sub bab ini akan diulas tentang formulasi dakwah untuk anak korban bencana alam. Dalam memformulasikan dakwah ini penulis akan berangkat dari pemahaman secara komprehenship terhadap kondisi anak, kemudian dikonfirmasikan dengan perjalanan dakwah pada bencana alam yang telah dilakukan sebelumnya (walaupun secara spesifik belum sesaui dengan standar dakwah terhadap anak korban bencana alam). Upaya pembahasan secara menyeluruh ini diharapkan dapat memberikan nilai tersendiri dalam pelaksanaan dakwah bagi anak korban bencana alam ke depan.

Sebagaimana telah disampaikan di atas, bahwa dakwah yang diberikan terhadap anak (berdasar pengalaman gempa di Klaten dan Yogyakarta) belum spesifik mengarah pada dakwah secara intensif. Treatmen atau perlakuan relawan bencana kepada anak-anak hanya sebatas mengalihkan pandangan anak dari "beban psikologis" menuju kestabilan psikis. Belum ada materi dakwah secara khusus yang diberikan kepada anak-anak korban bencana alam. Mereka memberikan terapi sebatas pada pemberian ruang bermain anak-anak. Untuk itu perlu dirumuskan dakwah yang sesuai untuk diaplikasikan pada anak korban bencana alam, yang dalam penelitian ini peneliti rumuskan sebagai dakwah bi al lu'bah.

Sebagai langkah awal dalam memformulasikan metode dakwah ini yang perlu ditekankan adalah tujuan yang hendak dicapai oleh seorang da'i. Metode ini secara umum digunakan sebagai upaya untuk menstabilkan kondisi psikologi mad'u dengan menggunakan permainan sebagai alat untuk mencapai tujuannya dalam memberikan materi dakwah yang dibutuhkan oleh mad'u. Pelaksanaan metode dakwah bi al lu'bah secara khusus mempunyai target dan tujuan sebagai berikut;

1. Tujuan dasar dalam penggunaan metode ini adalah untuk mendapatkan kenyamanan anak, baik pikiran, emosi, sikap, dan tingkah laku anak

2. Tujuan lain adalah untuk meringankan beban orang tua dalam menjalani kehidupan pasca bencana, dimana dirinya tidak perlu menkhawatirkan kondisi anaknya

3. Memastikan untuk perumusan kegiatan dakwah bagi anak, sehingga materi dakwah yang diberikan betul-betul sesuatu yang dibutuhkan untuk perkembangan batin anak korban bencana itu sendiri

4. Metode ini mempunyai tujuan sebagai pengejawantahan pemenuhan hal akan, sebagaimana yang telah digariskan dalam undang-undang perlindungan anak (Undang-undang Nomor 23 tahun 2002) sekaligus menjaga keturunan (al Qur'an surat Al Tahrim ayat 6) 
5. Mendahulukan kepentingan anak dalam berespresi dan mencapai kebebasan dalam koridor ajaran agama Islam dan tata laku yang berlaku di masyarakat

6. Menciptakan pola hubungan yang harmonis antara anak dengan keluarganya, anak dengan anak lain dan anak dengan lingkungannya

Untuk menjalankan metode dakwah bi al lu'bah dibutuhkan beberapa piranti atau unsur sesuai dengan dakwah pada umumnya, yaitu da'i, mad'u, konsep permainan, materi dakwah, dan medianya. Berikut ini digambarkan secara singkat implementasi komponen yang dibutuhkan unsur dakwah dalam menggunakan metode dakwah bi al lu'bah yang peneliti hasilkan;

1. Da'i

Da'i merupakan seseorang yang berusaha mengubah situasi kepada situasi yang sesuai dengan ketentuan-ketentuan Allah SWT, baik secara individu maupun secara kelompok (Organisasi), dan sekaligus sebagai pembawa misi tertentu (Anshari, 1993: 104). Dalam melaksanakan dakwah bi al lu'bah, da'i harus mempunyai keahlian dalam menangani anak. Dirinya harus paham betul terhadap psikologi perkembangan anak. Tahapan perkembangan anak dan kecenderungan yang dimilikinya harus dipahami sebagai sebuah keharusan bagi da'i yang akan menjalankan metode ini. Seorang da'i harus mampu mengerti karakteristik masingmasing anak dilihat dari umur, jenis kelamin dan kecenderungannya. Dengan memiliki kepiawaian dalam usaha memetakan keberadaan anak ini, dirinya mampu dalam memberikan perlakuan terhadap anak. Singkatnya seorang da'i harus mempunyai kepiawaian dalam berdakwah dalam segmentasi mad'u yang berbeda-beda.

2. Mad'u

Mad'u merupakan unsur yang harus diperhitungkan dalam kegiatan dakwah. Metode dakwah bi al lu'bah berusaha menyasar madu'u dari segi anak, bukan dewasa. Perubahan kognitif, afektif dan psikomotorik anak merupakan target yang hendak dicapai oleh da'i. Penggunaan metode yang sesuai dengan tingkat perkembangan dirinya baik secara individu maupun kelompok, tingkat berfikir, kondisi sosial-ekonomi, tingkat keberagaman dan keberagamaan, usia, jenis kelamin, dan sebagainya merupakan prasyarat yang harus dipenuhi oleh da'i.

Memposisikan mad'u yang akan dijadikan sebagai obyek penggunaan metode permainan ini diarahkan pada pengelompokan tersendiri dari masing-masing ciri dan karakteristiknya, sehingga perlakuan yang akan diberikan dapat dipertanggjawabkan. Dayaguna metode permainan bagi mad'u ini paling tidak memberikan nilai tersendiri untuk kesuksesan dakwah. Dengan mengerti segmentasi mad'u ini juga memberikan dampak pada penggunaan dan pemanfaatan metode permainan yang diberikan. Dengan demikian, kondisi mad'u harus dijadikan sebagai sebuah pemikiran tersendiri oleh da'i dalam menjalankan metode ini.

3. Konsep Permainan

Permainan yang digunakan dalam dakwah harus mempunyai nilai yang betul-betul kemanfaatanya dapat dirasakan oleh mad'u. Pembagian konsep permainan yang digunakan menjadi sesuatu yang wajib untuk 
dipikirkan da'i. Kesalahan penempatan permainan dalam dakwah akan mengurangi keberhasilan dakwah itu sendiri. Permainan sebagai metode dakwah paling tidak mempunyai ciri khusus yang membedakan dengan kegiatan lain yang serupa, yaitu trauma healing. Batasan permainan dalam dakwah harus disandarkan pada permainan-permainan yang dibolehkan secara syariat Islam.

Pembatasan bentuk dan konteks permainan ini secara garis besarnya adalah wujud permainan yang tidak bertentangan dengan ajaran agama. Permainan-permainan tersebut mempunyai nilai dakwah, bahkan juga tersisipkan didalamnya materi-materi dakwah yang memang telah dikonsep oleh seorang da'i. Permainan umum (yang berlaku di masyarakat) dipilih, untuk kemudian diberikan "pembeda"nya dengan pola permainan asalnya. Ini penting sebagai upaya untuk memberikan dampak positif dalam memberikan "kesembuhan" trauma bagi anak korban bencana alam, sekaligus sebagai ajang penguatan batiniyah mereka.

Ukuran peningkatan batiniyah memang tidak dapat disamaratakan antar mad'u, namun paling tidak ada muatan-muatan yang memberikan memberikan nilai lebih atas perubahan terhadap dirinya. Dengan perubahan tersebut hakekatnya ini merupakan indikator yang penting untuk dicapai. Selain itu, dengan perubahan mad'u anak memberikan dampak juga untuk mad'u dewasa yang merasakan perbedaan pada diri anak itu sendiri.

\section{Materi Dakwah}

Di atas telah digambarkan materi-materi yang dibutuhkan oleh anak korban bencana alam. Semuanya berpulang pada kepiawaian da'i dalam mengemas materi dakwahnya. Unsur materi yang paling penting adalah mengarahkan mad'u untuk dapat menerima musibah dan memaknainya sebagai sebuah ujian yang akan membawa berkah bagi kehidupannya. Selain itu materi tentang kesabaran, kepedulian terhadap sesama dan lingkungan sekitar mad'u menjadi sebuah alternatif pilihan yang perlu untuk disampaikan melalui permainan yang dipilih.

Dalam memberikan materi dakwah kepada anak, apalagi kepada mereka yang menerima musibah bencana tidak perlu menggunakan materi yang mempunyai isi berat. Mereka hanya membutuhkan materi yang sederhana dengan penggambaran yang mudah dicerna dan dipahami. Materi diberikan sebagai upaya untuk penyadaran diri sekaligus sebagai bentuk do'a untuk perubahan nasib yang menimpanya.

Menengarai hal tersebut, yang terpenting untuk dilakukan da'i adalah memberikan format materi dakwah dalam permainan yang akan digunakan. Penggabungan dan pengemasan materi dakwah dengan praktek permainan menjadi kata kunci keberhasilan dakwah yang dilakukan. Materi dakwah tidak harus menggunakan dalil-dalil yang "njlimet", melainkan konten materi disesuaikan dengan bentuk permainan itu sendiri. Kesesuaian hal ini memberikan manfaat dalam upaya pemberian materi pada segmentasi anak-anak yang titik fikusnya minim. 


\section{Media}

Dakwah dapat menggunakan berbagai wasilah atau media yang dapat merangsang indra-indra manusia serta dapat menimbulkan perhatian untuk menerima dakwah. Asumsi sementara yang dapat diungkapkan adalah semakin tepat dan efektif media yang dipakai, maka semakin efektif pula pemahaman materi dakwah yang diberikan. Media yang dapat digunakan dalam menggunakan metode permainan sebetulnya kembali pada bentuk permainan itu sendiri. Banyak permainan yang membutuhkan media tertentu dalam implementasinya. Namun, banyak pula permainan yang tidak membutuhkan media sebagai sarana implementasinya. Media dalam penggunaan metode ini dapat menyatu dengan permainan yang dimainkan, juga tidak menutup kemungkinan berdiri sendiri atau sifatnya penyempurna metode.

Untuk memilih media dalam dakwah dengan metode permainan ini, yang diperlukan adalah mengetahui kepiawaian mad'u dalam menggunakan media, tingkat keseringan mad'u dalam mengakses media yang dipilih dan kecenderungan pemilihan mad'u terhadap media. Dengan mengetahui tiga hal ini paling tidak tergambar karakteristik mad'u sekaligus kecenderungan mad'u terhadap permainan yang digamari. Hal ini penting untuk menyesuaikan akses mad'u terhadap bentuk permainan yang ada.

\section{Kesimpulan}

Akhir dari pembahasan artikel ini dapat disimpulkan bahwa dakwah bagi anak korban bencana alam mendapatkan perhatian yang minim. Para da'i seolah "melupakan" segmentasi anak sebagai mad'u yang perlu untuk mendapatkan materi dakwah. Kenyataan ini penulis jumpai di lokasi bencana di Klaten dan Yogyakarta, dimana anak-anak hanya mendapatkan trauma healing dari para relawan yang notabene tidak mengedepankan muatan keagamaan di dalamnya. Kegersangan jiwa terhadap materi dakwah untuk anak dirasakan oleh anak dan orang tuanya. Kenyataan ini mengindikasikan pentingnya pengemasan dakwah menggunakan media dan metode yang sesuai dengan segmentasi anak-anak. Reformulasi dakwah bi al-lu'bah dapat dilakukan dengan tiga cara, yaitu Pertama, penyusupan materi dakwah pada permainan yang lazim digunakan, Kedua, membuat permainan dakwah, dan Ketiga, membuat syair tentang materi dakwah melalui lagu-lagu populer yang dapat mudah diingat. Ketiga formulasi metodologis ini dapat dikembangkan lebih lanjut sebagai bagian dalam menyusun permainan-permainan yang disukai anak-anak. Perkembangan teknologi informasi, dimana anak-anak di masa kekinian lebih menyukai games berbasis gadget, mensyaratkan pelaku dakwah untuk memberikan muatan dakwahnya menggunakan media ini. Terobosan dalam membuat aplikasi permainan untuk dakwah sepertinya sesuatu yang tidak dapat disangkal lagi. Ini penting untuk menyesuaikan bentuk permainan yang lebih disukai anak-anak.

Alhamdulillah, puji syukur artikel ini dapat terselesaikan, walaupun masih banyak kekurangan baik dari tata tulis maupun kontennya. Peneliti menyadari masih banyak segmen yang belum dapat tuntas terbahas, maka kritik dan saran sangat dinantikan demi kesempurnaan pembahasan dalam kaitannya penangannya anak-anak korban bencana alam. Wallahu al a'lam 


\section{Daftar Pustaka}

\section{Buku}

Anshari, Hafi., Pemahaman dan Pengalaman Dakwah. Surabaya: Al-Ikhlas, 1993

Arifin, Anwar ,Dakwah Sebagai Gejala Sosial, Ujung Pandang: Yayasan Ikhtiar, 1996

az-Zaid, Zaid Abdul Karim, Dakwah bil Hikmah, Jakarta: Pustaka al-Kautsar, 1993

Bachtiar, Wardi, Metodologi Penelitian Ilmu Dakwah, Jakarta: Logos, 1997

Badan Pengembangan dan pembinaan Bahasa, Kamus Besar Bahasa Indonesia, Jakarta: Balai Pustaka, 2010

Chomaria, Nurul, Pendidikan Karakter Untuk Anak, Solo: Aqwan, 2012

Dahlan, H.A.A dkk (ed), Terjemah Hadits Mengenai Pribadi dan Budi Pekerti Rasulullah SAW, Bandung: CV. Penerbit Diponegoro, 1995

Departemen Pendidikan dan Kebudayaan, Kamus Besar Bahasa Indonesia, Jakarta: Balai Pustaka, 1990

Durand dan Barlow, Psikologis Abnormal, Yogyakarta: Pustaka Pelajar, 2006

Hurlock, E.B. Psikologi Perkembangan: Suatu Pendekatan Sepanjang Rentang Kehidupan, (terj), Jakarta: Erlangga, 1999

Kotler dan Keller, Manajemen Pemasaran, Jakarta: Erlangga, Jilid 1 Edisi 3, 2009

Kusumaningrum, Nirmala Ika dkk., Bahan Bacaan Pelatihan Penguatan dan Pemulihan Psikososial Untuk pendamping HAM, Jakarta: Yayasan Pulih, 2015

Mendato, Acmanto, Pemulihan Trauma: Strategi Penyembuhan Trauma Untuk Diri Sendiri, Anak, Orang Lain di Sekitar Anda, Yogyakarta: Panduan , 2010

Muriah, Siti, Metodologi Dakwah Kontemporer, Yogyakarta: Mitra Pustaka, 2000

Muslichatun, Metode Pengajaran di Taman Kanak-kanak, Jakarta: Rineka Cipta, 2004

Normalasari, Swastika Ayu, Terapi Trauma Anak Untuk Mengurangi Simpton Gangguan Stress Pasca Trauma, Yogyakarta: Universitas Gadjah Mada Press, 2009

Nottingham, Elizabeth K, Agama dan Masyarakat: Suatu Pengantar Sosiologi Agama, Jakarta: Rajawali, 1995.

Patilima, Hamid dkk, Pedoman Standar Layanan Kesiapan Keluarga Hadapi Bencana, Jakarta: Deputi Bidang Perlindungan Anak Kementerian Pemberdayaan Perempuan dan Perlindungan Anak, 2017

Piaget, Jean dan Barbel Inhelder, The Psychology of The Child, (terj), Jakarta: Pustaka Pelajar, 2010

Siswanto, H.B. , Pengantar Manajemen, Jakarta: Bumi Aksara, 2007

Slegel, Daniel J., Healing Trauma: Attachment Mind and Brain, New York: WWW Norton \& Company, 2003

Sulthon, Muhammad, Dakwah dan Sadaqat: Rekonseptualisasi dan Rekonstruksi Gerakan Dakwah Awal, Yogyakarta: Pustaka Pelajar, 2015

Undang-undang No 23 tahun 2002 tentang Perlindungan Anak, Jakarta: Visimedia, 2007

W.J.S. Poerwadarminta, Kamus Umum Bahasa Indonesia, Jakarta: Balai Pustaka, 1997

Zainu, Muhammad bin Jamil, Kaifa Nurabbi Auladana, Mesir: Maktabah al-huda, 2002 Zakaria, Bakar al-Da'wah ila al-Islam, Mesir: Dâr al-'Urulah, tt.

\section{Jurnal dan Laporan Peneltian}

Ghoni, Abdul, Efektivitas Program Perlindungan Anak Terpadu Berbasis Masyarakat (PATBM) Dalam Mencegah Kekerasanterhadap Anak Di Kabupaten Kebumen Jawa Tengah, Semarang: Laporan Penelitian DIPA UIN Walisongo, 2017

Widyastuti, Citra dkk, Play Therapy Sebagai Bentuk Penanganan Konseling Trauma Healing Pada Anak Usia Dini, Yogyakarta: Jurnal Hisbah, Vol 16, No.1 2019 
Yusriyah, The Reconsctruction of Islamic Theology in the Unity of Sciencies, Semarang: Jurnal Walisongo, Vol 23 No 2, 2015

\section{Internet}

Handoko, T. Hani, Manajemen, Yogyakarta: BPFE, 2000

https//id.m.wikipedia.org diakses tanggal 18 september 2018

https:// dosenpsikologi.com/terapi-aktivitas-kelompok, diakses pada tanggal 26

Agustus 2019

https://bincangsyariah.com/kalam/tafsir-apa beda-kata-laibun-dan-lahwun-dalam al qul'an. 